\title{
The role of agritourism in the development of rural territories in the union state of russia and belarus
}

\author{
N.Z. Goncharova ${ }^{1}$, E.S. Vorobeva ${ }^{1}$, and O.B. Tarasova ${ }^{2}$ \\ ${ }^{1}$ Smolensk State Agricultural Academy, Smolensk, Russia \\ ${ }^{2}$ Russian State Agrarian University - MTAA, Moscow, Russia
}

\begin{abstract}
The purpose of the study is to assess the state and prospects of rural tourism development as one of the priority areas of economic activity in the agricultural sector of Russia and Belarus and its place in the European market of tourist services. The history of development of agritourism in the world economy is analyzed, the specifics of different countries are noted, and the advantages of agritourism in the Union State are shown. The study was carried out using classical methods of comparison, analysis of dynamic series, and analytical groupings. The modern economic literature highlights the main directions of agritourism development in the world, the impact of investments in agritourism on rural development, and the retention of rural population in Russia and Belarus. The main attention in this article is focused on the advantages of rural tourism in Russia and Belarus in comparison to rest of the European market of tourist services, which can facilitate attracting foreign tourists. At the same time, the strengths and weaknesses of this type of economic activity in the Union State in comparison to the neighboring countries are discussed. Russian regions are grouped by the level of rural tourism development, and the level of investment in agriculture is assessed. The study allowed us to identify the "bottlenecks" in the development of rural tourism in Russia and Belarus and to identify the most important objective and subjective reasons for their occurrence. In the conclusion the article offers a set of recommendations that will allow using the specific natural and climatic features of the Union State to attract state and private investment contributing to the development of agritourism and rural terrritories.
\end{abstract}

\section{Introduction}

Business tourism as a type of commercial activity emerged in the developed capitalist countries of Europe and the United States of America in the 70s of the last century and in a relatively short time took one of the leading places in the economy.

In today's world large foreign companies spend over a billion dollars annually on business trips and stimulating travel for their employees. The business tourism costs are one of the priority items of production expenses. Leaders in the field of business tourism are the United States of America, Great Britain, Australia, Germany, France, Japan, China, and 


\section{South Korea.}

Agritourism as a sphere of economic activity has a significant impact on the development of agriculture in Russia and Belarus and on the economy as a whole. The industry is in the process of formation, so there is a set of problems that both the subjects of agritourism and the state of both countries are facing. In the system of national accounting of Russia and Belarus, rural tourism, or agritourism as an economic activity, is defined as a "journey in rural areas, during which tourists experience a rural lifestyle, engaging in agricultural work, and also have the opportunity to study local culture and customs" $[5,6]$. The purpose of the study is to assess the current state of agritourism in the Union State, identify the problems of this type of economic activity and propose possible solutions.

\section{Materials and methods}

The study of the topic was based on statistical materials for the regions of the Russian Federation and statistical data on tourism and tourist activities in the Republic of Belarus. The classical research methods were applied, such as: statistical observation, comparison, analysis of dynamic series, statistical groupings, collection, processing and analysis of data on the regions of the Russian Federation and the regions of Belarus, and assessment of the successful regional practices in the development of rural tourism in the Union State.

\section{Results and discussion}

From an economic and philosophical points of view, there are several concepts of rural tourism that were developed taking into account the specific conditions for the development of agritourism in different countries of the world. Thus, the countries of Western Europe consider agritourism as a way to switch a certain part of the rural population from the production sector to the service sector by organizing a small family-type business. Wherein, a whole range of tasks is being solved: economic, social, and cultural. Such a concept is most acceptable for depressed rural regions and helps to stop their degradation. Eastern European countries and a number of CIS countries stick to the concept of building an agritourism industry by state regulation and financial support through preferential credit programs, the implementation of which allows for the reconstruction and equipment of rural housing to increase the comfort of tourists. The concept for the "third world" countries is based on the use of unique natural, climatic, historical and cultural features of the countries and involves the creation of private tourist centers in rural areas at the expense of investors. The concept of creating "multifunctional state agricultural parks" [4] is typical for the United States of America and economically developed countries of the world, the main goal of which is ideological. It consists in promoting of the achieved level of development of the country's agriculture, popularization of progressive technologies for growing agricultural crops, and keeping productive animals. The peculiarity of these objects of the rural tour industry is their departmental affiliation to the Ministry of Agriculture. Agricultural parks perform many functions: scientific research, selection, exhibition, entertainment.

Russian and Belarusian scientists approach the terms "agritourism" and "rural tourism" from different points of view $[3,7,8]$. Thus, according to S. V. Pinyaev, D. V. Sevastyanov and A. B. Zdorov, agritourism, ecotourism, ethno-tourism, esotourism are unambiguous categories, indicating a rural rest. At the same time, thus, S.V. Pynyaev belives that in rural areas various types of educational and ecological tourism are developing, while agritourism has become widespread in Europe and North America. In the world classification, agritourism is referred to as one of the types of ecotourism" $[4,5,14,15]$. D. V. Sevastyanov 
defines ecotourism as "nature-oriented travel" and considers agritourism and agroecological tourism (agro-ecotourism) as" green" tourism. Agritourism "... focuses on the use of natural, historical, cultural and other resources of rural areas, it is associated with the organization of recreation and travel in the rural environment, with life on farms, acquaintance with rural life, with participation in agricultural work " [9,10,11]. A.B. Zdorov believes that ecotourism is an integral part of agritourism in terms of "... structuring the considered form of tourist activity as such". According to A. I., Panyukov, Yu. G. Panyukova and I. V. Smirnov, the concept of agritourism is not limited exclusively to visiting the village yard and communicating with animals, agritourism is a small town and the surrounding rural territory, therefore, the production of agricultural products and their way to the tourist's table can also be a popular type of rural tourism. Among the CIS countries, the Republic of Belarus was the first to adopt the concept of agriculturist $[1,13]$. A number of researchers in Russia and Belarus believe that "rural tourism" is a broader concept that includes also such types of tourism as farming, peasant and agrarian" $[2,12$, 16]. According to Polish scientists M. Schneider and L. Przezburska, rural tourism covers all aspects of tourism in rural areas [14]. Russian and Belarusian scientists believe that the main difference between rural and agricultural tourism is the tourist's attitude: rural tourism is contemplation and enjoyment, while agricultural tourism is active recreation associated with participation in agricultural work such as crop production and farming $[1,10,11]$.

In the Union State of Russia and Belarus, the business tourism industry began to form 20 years later and is associated with the collapse of the USSR and the transition to a market economy. In recent years, this type of activity has been developing quite rapidly and is considered one of the priority and promising areas of business. Rural tourism, or agritourism, occupies a special niche due to the specific features of tourist activities. In both countries between 2008 and 2015 special program documents were adopted that regulate alternative employment of the rural population with appropriate financial support, providing preferential conditions for lending to entrepreneurs in the field of rural tourism.

In 2006, experts of the world tourism organization conducted a rating assessment of the European part of the Russian Federation in terms of favorable natural and economic conditions for agricultural production and agritourism on a ten-point scale, which showed that the regions of Russia are not equal in terms of conditions for these types of activities.

A comprehensive assessment of the conditions for agricultural development included soil fertility by the content of humus and basic chemical elements, as well as climatic conditions by the level of favorability for growing crops. The assessment of rural tourism included the presence of historical monuments, folk crafts, folklore, and a good transport network. The aggregate rating of the region is calculated as the sum of points for both types of activity. Comparison of regions shows that in terms of agricultural production and agritourism, the regions of Russia are not equal: the North-Western and Central regions are most favorable for the organization of agritourism, but unfavorable for the production of agricultural products. The opposite situation is developing in the Central black earth and southern zones. However, integral assessments in all regions of Russia are quite favorable from 5 points in the Western and Central Chernozem regions to 8 points in the southern one, which allows us to successfully develop agricultural production together with agritourism, when one type of economic activity complements another. This strategy is particularly relevant for the development of rural areas in the depressed regions of Russia bordering the Republic of Belarus and having a significant potential for the development of agritourism within the Union State.

In the Union State of Russia and Belarus, the business tourism industry began to form 20 years later and is associated with the collapse of the USSR and the transition to a market economy. In recent years, this type of activity has been developing quite rapidly and is considered one of the priorities and promising areas of business. Rural tourism, or 
agritourism, occupies a special niche due to the specific features of tourist activities. In both countries between 2008 and 2015. special program documents were adopted that regulate alternative employment of the rural population with appropriate financial support, providing preferential conditions for lending to entrepreneurs in the field of rural tourism.

In 2006, experts of the world tourism organization conducted a rating assessment of the European part of the Russian Federation in terms of auspiciousness of natural and economic conditions for agricultural production and agritourism on a ten-point scale. It showed that the regions of Russia are not equal in terms of conditions for these types of activities.

A comprehensive assessment of the conditions for agricultural development included soil fertility by the content of humus and basic chemical elements, as well as climatic conditions by the level of favorability for growing crops. The assessment of rural tourism included the presence of historical monuments, folk craft, folklore, and a good transport network. The aggregated rating of the region is calculated as the sum of points for both types of activity. Comparison of regions shows that in terms of agricultural production and agritourism, the regions of Russia are unequal: North-Western and Central regions are most favorable for the organization of agritourism, but unfavorable for the production of agricultural products. The opposite situation is developing in Central-Chernozem $\mathrm{s}$ and Southern zones. But the integral ratings in all regions of Russia are quite favorable - from 5 points in the Western and Central Chernozem regions up to 8 points in Southern, that allows us to successfully develop agricultural production together with agritourism, when one type of economic activity complements another. This strategy of rural development is particularly relevant in the depressed regions of Russia bordering the Republic of Belarus and having a significant potential for the development of agritourism within the Union State.

In the United States and Western Europe, rural tourism is a fairly profitable area of the tourism industry. So in France, 35 thousand farms with mini-hotels and Inns receive tourists; in England, farms with hotels for 120 thousand places are developed; in Germany, rural hotels receive 20 thousand tourists every year. In Italy, more than 15 million people spend their holidays on agricultural farms on the Apennine Peninsula every year. In Western Europe, about 40 million people choose agricultural tourism every year.

In Russia and Belarus, agritourism is in the process of formation, while all the directions accepted in the world practice are developing at the same time, which, taking into account international terminology, can be classified as follows:

- MICE - this group includes business meetings (Meetings); incentive tours for employees of a corporation, business partners, clients (Incentives); organization of conferences for the exchange of experience, thematic exhibitions (Conferences); corporative parties for various organizations (Events). Examples include regular International forums for rural tourism in Belgorod and the "Belye Klyuchi" business center in Karelia; boat cruises on the Don, hunting and fishing in the Rostov Region; interregional seminars on the development of rural tourism infrastructure in the Smolensk Region; Gazprom's corporate events at agricultural companies in the southern Urals and the Smolensk Region.

- Event-driven (individual type of recreation) - this group includes visits to rural areas to participate in local events and specially organized festivities. For example, "Goose fights", "Cucumber festival", "Indian summer" in the Suzdal District of the Vladimir Region; festival "Ybitsa" and " Jam Day "in the Finno-Ugric ethnocultural Park of Komi; world festival of ethnic music "Wild mint "in the Kaluga Region;" Bath day " in the Pskov Region.

- Educational - this type of activity involves recreation in rural areas in combination with teaching courses and internships. For example, master classes on folk crafts of the Yaroslavl region; international seminars in Karelia on the organization of rural tourism 
together with Finnish and Irish experts; teaching seminars "Reception of tourists in a rural house" in the architectural and ethnographic Museum-reserve "Kizhi".

- Gastronomic - a relatively new type of agritourism, which involves introducing tourists to the peculiarities of local cuisine while visiting a rural settlement. At the same time, dishes are prepared from environmentally friendly products produced on the territory and at the request of the tourist, with his participation. For example, "Lunch in the Russian hut" in the Yaroslavl Region; visiting wineries and vodka production with tasting, walking through the vineyards in the Krasnodar territory; relaxing in the bosom of nature, collecting wild berries, participating in the harvest in the Altai territory. The gastronomic direction of rural tourism is of particular interest in the territory of the Union State. It is becoming more and more popular and attracts not only domestic but also foreign tourists.

In the Republic of Belarus, rural tourism is defined in the classification of activities as agroecotourism. This is a successful type of economic activity with a certain specific development. The creation and development of agroecotourism began in 2006 after the signing of the corresponding Decree of the President of the Republic of Belarus. As a result, over the last 10 years, the number of farm tourism estates has increased 66 times, and the number of rural tourists has increased 30 times. Based on the results of the international competition 2016 (NationalGeographicTraveler) The Republic of Belarus is ranked first in Europe, while the demand for Belarusian rural tourism in the world market is constantly and steadily growing $[1,13]$. A feature of the development of this type of tourism activity in the Republic of Belarus is the participation in its management not only of the state, but also of the public Association "Rest in the village", which includes local residents who offer and develop events for the introduction and development of competitive types of tourist services in rural areas. Rural tourism in Belarus has been developing in recent years according to the following models:

The first model is the creation of agricultural theme parks in existing rural settlements. They are characterized by traditional national architecture and do not require significant financial investments. This model is used by the world-famous Museum of ancient technologies and crafts "Dudutki", The Museum of Belarusian architecture and everyday life "Strochitsy", The Museum"Belarusian village".

The second model is the creation of agritourism complexes based on large agricultural organizations of the agroindustrial complex with an effective level of production. The objects of this model include agroecotouristic complexes "Solovinaya Roscha", "Devino", "Vygoda", as well as agritourist complex "Garadzenskimaentak 'Karobchytsy”"on the basis of JSC "Grodno meat processing plant".

The third and priority model is the organization of tours with accommodation and meals in rural farm tourism estates, in fact a family hotel business, similar to the Western European concept. The specificity of this model is to attract private investment. The role of the state is limited only to creating a developed rural infrastructure, including a road network, route signs, organization of garbage collection in the forest and on the banks of reservoirs, etc., i.e., in fact, to solving a more global problem - the development of rural territories.

In the theoretical substantiation of the concept of rural tourism, scientists of Belarus, Russia and Ukraine use the specific term "farm tourism estate", denoting the object of agritourism, which is a rural house built in the traditional style. At the same time, farm tourism estates differ quite significantly in the degree of comfort of living: from an ordinary village house without amenities to a modern cottage with all amenities [5, p.14]. The farm tourism estate provides tourists not only with accommodation, but also with a wide entertainment program, including acquaintance with the local nature, culture and customs, communication with the villagers, participation in agricultural work, caring for cattle, collecting mushrooms and berries, medicinal herbs. Activities such as fishing, Russian bath, 
billiards, excursions, sports games, hiking, horse riding and cycling can be arranged.

The agritourism destination events - holding corporate events and parties in rural areas - is also developing successfully in Belarus. The natural and climatic conditions of Belarus correspond to the global trend - a turn from entertainment tourism (three S - sun, sea, sand) to content tourism (three L - landscape, lore, leisure). And in this direction Belarus is out of competition: it is a country of forests and reservoirs, rare pastoral landscapes and unique national parks. The competitiveness of Belarusian agricultural farm tourism estates in the European tourist market in recent years has been ensured by relatively low prices for rural recreation. Agroecotourism in this country is also an excellent way of improving health, since Belarus is considered the "lungs of Europe" [13,14,15].

The organization and development of rural tourism are impossible without significant investments to create rural infrastructure, since it is this infrastructure that ensures the attractiveness and accessibility of tourist services in rural areas. As already noted, the financing of domestic agriculture has always been carried out "according to the residual principle", and this trend, unfortunately, has not been reversed at the present time. In this regard, most of the rural areas of modern Russia have an almost undeveloped infrastructure, which is unattractive for tourists, especially foreign ones. This is especially true for impassable rural roads, that makes it almost impossible to travel by private vehicle. Investments in rural infrastructure are high-risk, because they do not always bring profit and therefore do not pay off. In this regard, private investors are not in a hurry to invest in rural areas, and public investment is allocated in general to the development of agriculture, without allocating the target part to infrastructure. At the same time, their level is extremely low (table 1).

Table 1. Differentiation of regions of the Russian Federation by the level of state investment in agriculture

\begin{tabular}{|c|c|c|c|c|c|c|}
\hline \multirow{2}{*}{\multicolumn{2}{|c|}{$\begin{array}{l}\text { Groups by } \\
\text { agricultural } \\
\text { investment based on } \\
\text { per person of rural } \\
\text { population, thousand } \\
\text { rubles }\end{array}$}} & \multicolumn{2}{|c|}{$\begin{array}{l}\text { Investments on average } \\
\text { per capita, thousand } \\
\text { rubles }\end{array}$} & \multirow{2}{*}{$\begin{array}{l}\text { Index of } \\
\text { investments, } \\
\% \text { of the } \\
\text { previous } \\
\text { year }\end{array}$} & \multicolumn{2}{|c|}{ Specific weight, $\%$} \\
\hline & & $\begin{array}{l}\text { economy } \\
\text { in general }\end{array}$ & $\begin{array}{l}\text { including } \\
\text { agriculture }\end{array}$ & & $\begin{array}{l}\text { rural } \\
\text { population } \\
\text { in total }\end{array}$ & $\begin{array}{l}\text { investment in } \\
\text { agriculture in } \\
\text { total }\end{array}$ \\
\hline up to & 2012 г. & 68,8 & 3,5 & 115,3 & 33,1 & 3,1 \\
\hline 9,5 & 2019 г. & 85,3 & $\overline{5,6}$ & 113,2 & 26,9 & 2,1 \\
\hline $9,5-$ & 2012 г. & 83,4 & 8,9 & 118,9 & 28,8 & 7,0 \\
\hline 15,5 & 2019 г. & 103,4 & 14,2 & 117,1 & 23,4 & 4,4 \\
\hline over & 2012 г. & 83,6 & 18,9 & 116,3 & 30,9 & 12,7 \\
\hline 15,5 & 2019 г. & 103,7 & 30,1 & 114,8 & 25,1 & 8,3 \\
\hline
\end{tabular}

Thus, 56\% of Russian regions receive an average investment of 5.6 thousand rubles. per rural resident (from 1.2 thousand rubles in Ingushetia, up to 8.9 thousand rubles in the Kemerovo region). The most favorable situation with investments has developed in the regions of the Central Federal district, which is the leading region in the country in terms of economic development. As it can be seen from the table, there are four-fold differences in the size of investments for groups of regions, at the same time, there is reason to assert that in all interval groups, investment is carried out according to the already known "residual principle", since the share of investment in agriculture, even in relatively prosperous regions, does not exceed $13 \%$ of the total of investments in the economy. At the same time, 
there is an extremely negative trend: we can note a deterioration in the dynamics of conditions for sustainable development of rural territories, that was manifested in a decrease in the specific weight of the rural population, a decrease in the rate of annual growth and the specific weight of investments in agriculture.

With such an investment policy of the state, it is difficult to count on creating infrastructure in rural areas that meets the requirements of modern tourists, most of whom live in large cities and are used to a certain level of comfort. The organization of rural tourism in the Union State of Russia and Belarus objectively differs from the EU countries, where there is an overproduction of agricultural products, and the state's efforts are aimed at providing alternative employment in rural areas. Domestic agritourism is designed to solve a broader list of tasks: to provide agricultural employment in the off-season period; to provide the rural population with food and income at the cost of personal subsidiary farming; to create conditions for the preservation and development of rural territories. Public investments in agriculture are of crucial importance for the development of agritourism, as they allow developing rural infrastructure and ensuring the accessibility and attractiveness of rural recreation (table 2).

Table 2. Impact of the average per capita level of investment in agriculture on the development of rural tourism in the regions of the Russian Federation, 2019

\begin{tabular}{|c|c|c|c|}
\hline $\begin{array}{c}\text { Groupsd by } \\
\text { agricultural } \\
\text { pervestment based on } \\
\text { person of rural } \\
\text { population, thousand } \\
\text { rubles }\end{array}$ & $\begin{array}{c}\text { Investments in } \\
\text { per capita of the rural } \\
\text { population, } \\
\text { thousand rubles }\end{array}$ & $\begin{array}{c}\text { Number of } \\
\text { regions with } \\
\text { relatively } \\
\text { developed rural } \\
\text { tourism }\end{array}$ & $\begin{array}{c}\text { Specific weight of } \\
\text { objects of Federal } \\
\text { significance in the } \\
\text { total number of } \\
\text { objects, } \%\end{array}$ \\
\hline up to 9,5 & 5,6 & 7 & 41,2 \\
\hline $9,5-15,5$ & 14,2 & 7 & 35,3 \\
\hline over 15,5 & 30,1 & 6 & 23,5 \\
\hline
\end{tabular}

According to Rosstat data, as of 1.01.2019, 4.5 thousand of rural tourism objects were registered in the Russian Federation. while most of them are concentrated in groups 1 and 2 of regions where investment in agriculture is 2 to 5 times lower than in the highest, 3rd group. It once again confirms the previously made conclusion that rural tourism in regions with unfavorable conditions for agricultural development plays a substitute role and is the only way to preserve and sustainably develop rural territories, especially in depressed regions. In the rating of Russian regions with developed agritourism, the leading place is occupied by the Krasnodar territory, where agricultural tourism is included in the Concept of development of the region's sanatorium and resort complex until 2030 as a strategic direction for sustainable rural development. The region has more than 100 agricultural tourism facilities located in 24 districts of Kuban, the main part of which is concentrated around Novorossiysk, Anapa, Sochi and Gelendzhik. In 2014-2017, the number of agritourism objects in the Krasnodar region increased by 2.5 times, because the regional administration considers this type of activity promising for the development of rural territories and finances it. Kuban is also successfully developing a specific direction of gastrotourism-alcotourism, which allows you to get acquainted with the production technology of the world-famous brands "Villa Romanov","Abrau-Durso","Wine village".

In Belarus, rural tourism is developing quite successfully, and its experience can be used by rural entrepreneurs in Russia. In 2016, according to the rating of National Geographic Traveler Awards, the Republic with the brand name "farm tourism estate" took the first place in the nomination "Agritourism". The competitive advantages of rural 
tourism in the country are also provided by very low rent by European standards (from 200 Russian rubles per day). This type of rural tourism is in great demand among Russian tourists with different levels of solvency. In Belarus, the development of agroecotourism over the past five years is characterized by a positive trend (table 3 ).

Table 3. Dynamics of indicators of agroecotourism development in the Republic of Belarus

\begin{tabular}{|l|c|c|c|c|c|}
\hline \multicolumn{1}{|c|}{ Indicators } & 2015 & 2016 & 2017 & 2018 & 2019 \\
\hline $\begin{array}{l}\text { Thumber of subjects of } \\
\text { agroecotourism, units }\end{array}$ & 2263 & 2279 & 2319 & 2473 & 2760 \\
\hline $\begin{array}{l}\text { The number of tourists served by the } \\
\text { agroecotourism, thousand people }\end{array}$ & 294,3 & 301,8 & 351,1 & 422,3 & 514,8 \\
\hline $\begin{array}{c}\text { including citizens of the } \\
\text { Republic of Belarus }\end{array}$ & 261,3 & 271,4 & 317,5 & 379,2 & 465,7 \\
\hline $\begin{array}{c}\text { citizens of other countries } \\
\text { Average length of stay, days }\end{array}$ & 42,9 & 30,4 & 33,6 & 43,1 & 49,0 \\
\hline $\begin{array}{l}\text { Cost of services provided, USD million } \\
\text { (at the current exchange rate) }\end{array}$ & 10,1 & 7,8 & 8,8 & 10,2 & 11,9 \\
\hline
\end{tabular}

The main part of tourist services is realized in the domestic market of Belarus. To date, Belarus has successfully operated more than two thousand farm tourism estates located in the most picturesque area. The largest number of foreign tourists arrive in Belarus from Russia (about 70\%), the rest of them are from the Baltic States, Ukraine, Poland, and Germany. The distribution of agroecotourism subjects on the territory of Belarus, as in Russia, is uneven: the main part of tourist sites is concentrated in the Minsk, Vitebsk and Brest Regions. The market for outbound agritourism in Belarus is still poorly developed. The main direction of rural tourism development is the domestic market, which is favored by a decrease in the effective demand of the population for foreign tourism. A survey conducted in social networks $[11,13]$ showed that the popularity of rural tourism in both countries increases especially in the off-season, when urban residents rent houses in villages to relax on weekends and taste local cuisine.

The study conducted allows us to predict the development of rural tourism in the Union State using two models:

The first one is performed simultaneously with the development of agricultural production, when in addition to receiving tourist services, guests have the opportunity to buy environmentally friendly products produced in an agricultural organization that develops agritourism as an addition to the main activity - the production of agricultural raw materials. If the main activity is unprofitable, agritourism can provide the final positive financial result.

The second one is as an independent and priority type of economic activity in rural territories, if agricultural production in such a territory is inefficient, and other forms of employment of the rural population are required in order to maintain or stop the decline of the rural population. In this model, agritourism will be the main source of tax revenues to the local budget, and, consequently, the main factor in the sustainable development of rural areas.

A promising direction of rural tourism in both countries of the Union State is gastronomic routes, the basis of which will be "green", i.e. rural, gastrotourism, the value of which lies in the ecological purity of the products used. In recent years, attitudes towards people with disabilities have changed radically in Russia and Belarus. In this regard, a new direction in agritourism has appeared - the organization of inclusive tours for visiting farm tourism estates by disabled tourists.

In our opinion, the main feature of agritourism in the Union State is a deeper penetration into rural life and mode of life. While in most European countries, agritourism is understood as an ordinary vacation in a rented farmhouse, in Russia and Belarus, the 
concept of agritourism includes an agricultural component, which implies active participation in agricultural work, care for productive animals, and processing of agricultural raw materials. Familiarization tours to dairy farms, poultry houses, apiaries, and cheese factories are in high demand in the domestic market of agricultural services. Adding a local history component and meetings with local artisans to the agricultural tours allows tourists to diversify their leisure time. The Russian project "Power of the village" aims to show tourists a fundamentally different from the city, but at the same time a modern and comfortable way of life.

The main goal of agritourism is to create an additional source of income to maintain the profitability of agricultural activities. For agricultural producers, agritourism is a diversification of activities that increases the stability of production, which is especially important during the off-season, when the main sources of income for rural residents can be master classes on folk crafts, familiarization tours to modern farms with contact communication with animals, tasting products in the format of a farm breakfast or lunch, selling finished products, the income from which can reach $70 \%$ of all earnings on agritourism [9].

Agritourism in Russia is also of interest to agricultural holdings, but the motivation is not to generate income, but to create a positive image. Thus, close corporation "Lenin state Farm" on the border with Moscow created a contact village that shows the history of labor on the land, the age-old traditions of Russian rural mode of life, and where the younger generation of urban and rural children can communicate with animals, get primary skills in milking a cow, grind flour on an ashtray, plow the land with a real plow [11]. The project is educational in nature and allows pupils of urban schools to assess the peculiarity and necessity of peasant labor.

The Concept of rural tourism development in Russia for the period 2016-2030 has been developed and adopted in Russia. The concept was developed on the basis of state programs for the development of the Russian Federation in general and the development of domestic and inbound tourism, and contains a set of measures to improve the efficiency of state management of this type of activity. Agritourism does not require significant public investment (with the exception of depressed regions), but it has a multiplicative effect in rural areas and is of great social significance, contributing to the creation of jobs, fastening of the rural population, and sustainable development of rural territories. The main type of agritourism organizations in Russia and Belarus, in our opinion, are small businesses, whose financial support is currently provided at the expense of targeted budget funds.

The advantages of rural tourism in Russia and Belarus consist in the specificity and diversity of historical, cultural and natural monuments, protected by UNESCO, unique natural landscapes, exclusivity of local customs and ceremonies, and also favorable geographical location in Europe. At the same time, there are common shortcomings in the development of agritourism in both countries: the quality of services provided, the discrepancy between price and quality, the lack of a marketing strategy, and the low level of rural infrastructure development. At the same time, Russia and Belarus have a shorter favorable summer vacation period compared to European countries. On the other hand, the territory of the Union State has unique opportunities for winter recreation in rural areas, which are not available in Europe.

\section{Conclusions}

In our opinion the successful development of rural tourism on the territory of the Union State of Russia and Belarus is possible under the following conditions:

1. Clarify and make official the content of the categories "agroecotourism" and "farm tourism estate" with an indication of the characteristic features of this type of economic 
activity and the type of rural settlement, since there is currently no unambiguous interpretation of these terms by scientists of the Union State. Rural tourism includes a variety of leisure activities: residence on private farms and estates; gastronomic tours with tasting dishes made from environmentally friendly products; participation in agricultural work; ethnic tours (acquaintance with the history and culture of the area); hiking in the forest, picking mushrooms and berries, hunting, fishing, horse riding. All these types of rural recreation can be combined within a single estate or farm, which helps to attract more tourists.

2. In Russia, develop and adopt a Federal target program for the creation of infrastructure of rural territories, which provides for various sources of public and private financing. Currently, such programs have been developed and are actively working only in some regions of the country: Belgorod, Kaluga, Leningrad, Tver Regions, Krasnodar and Altai Territories. When developing the program, it is advisable to use the experience of Belarus, in which the National program for tourism development was adopted and approved by Presidential decree 2.06.2006. "On measures to develop agroecotourism in the Republic of Belarus".

3. Provide a regulatory framework for the organization and development of agritourism, standardize and certify the quality and safety of agritourism services that meet international and domestic quality standards ISO and OKUN. It will allow developing agritourism on the territory of the Union State as a competitive sector of international tourism services. A significant disadvantage of the rural tourism industry at present is the lack of certification of rural houses for the placement of tourists, which remain outside of a clear legal framework. It makes the placement of tourists in them difficult and creates a precedent for controversial situations.

4. Ensure the training of qualified personnel, since only a manager trained in specialized departments of higher educational institutions in Russia and Belarus can successfully work in this business, who can organize training of economically active rural population in the basics of agritourism activities, attracting public organizations to conduct training seminars and provide constant advice on improving the skills and retraining of rural residents on the basis of agricultural educational institutions under special educational programs.

5. Create a single informational base. In Belarus, a statistical yearbook "Agritourism in the Republic of Belarus" is being formed, but it does not provide statistical data on income received from agritourism activities, that allows many entrepreneurs to conduct shadow accounting. In Russia, special statistical monitoring of rural tourism objects is not carried out at all, and statistical data on this type of activity are not included in the collections of economic indicators for Russia that makes it difficult to provide an analytical review. So far, only the public informational portal "AgritourismAssociation" works in Russia, where you can get general information about the state of agritourism.

6. When forming rural tours, it is necessary to take into account that for domestic tourists who choose rural tourism, comfortable accommodation conditions and the availability of familiar amenities are crucial, and foreign tourists consider the authentic features of the area as a priority (local living conditions, natural food, local traditions and folklore).

7. Comfortable rural tours are still very expensive (up to 10 thousand rubles per day), which is more expensive than sea tours, so rural tourism is in demand only among well-off groups of the urban population who do not have country cottages. In this regard, we need a state program of financial and juristic support for rural entrepreneurs in the field of agritourism, effective advertising and informational provision.

8. Develop a mechanism for smoothing the seasonality of demand for agritourism services in Russia and Belarus by organizing and intergration of off-season entertainment programs based on ancient holidays, ceremonies and customs: Maslenitsa, seeing off 
winter, rituals "Kalyady", "Kupalle", "Rusalle", "Vyaselny Karavay". Thus, the CNNgo portal assigned the winter caroling holiday in the village of Pogost in the Zhitkovichi District of the Gomel Region of Belarus the third place in the world among winter holidays $[1,13]$.

9. Provide the agricultural sector in tourism with modern informational technologies that allow creating a virtual market for agritourism services, which will allow owners of farm tourism estates to form a consumer market in accordance with current trends and carry out active advertising with the help of specialists.

10. Ensure the creation of a regional tourism product in the form of a cluster model that will allow combining all organizations related to agritourism activities in rural territories: business structures, state institutions, educational institutions of various levels, non-profit organizations. As the experience of other industries and activities shows, the cluster model allows you to optimize and minimize all available resources and increase the efficiency of their use. The so-called "green routes" can be considered as an example of a tourist cluster. In Belarus, this is the "Blue necklace Rosson", "Hegumen horse routes", "Land of yellow water lilies and gray boulders", "Neman way"; in Russia - "Road to the Laura" in the Moscow region, the reserve "Voroninsky" in the Tambov Region, the Caucasian biosphere reserve in Maykop, the ecofarm "Exarcho", the national Park" Alania " near Vladikavkaz and many others.

11. Ensure the development of one of the most promising areas of agroecotourism - the non-material heritage of Russia and Belarus. Belarus is represented by seventeen ancient ceremonies and customs in the UNESCO list of intangible cultural heritage. Russia can present more than fifteen agricultural, religious, and family ceremonies that have a local flavor and are of interest, first of all, for foreign tourists.

\section{References}

1. Ya.N. Anoshko, L.M. Gaidukevich, Agroclimatic potential of the Belarusian Polesie. Minsk: vobgu Publishing house, 2, 160 (2011)

2. N.Z. Goncharova, E.S. Vorobeva, S.E. Terentyev, O.B. Tarasova, International Conference on Policies and Economics Measures for Agricultural Development (AgroDevEco 2020). Advances in Economics, Business and Management Research, 30 July 2020 (2020)

3. B.A. Zdorov, M.A. Zdorov, V.V. Abryandina, Scientific Herald of MGIIT, 5(31) (2014)

4. I.V. Lebedeva, S.A. Kopylov, Rural tourism as a means of rural development. Moscow: ANO "ARSI", 164 (2018)

5. A.I. Panyukov, Yu.G. Panyukova, Theory and practice of social development, 2, 242(2013)

6. Prospects for the development of agritourism in Russia, http: // www. agritourism. ru/

7. S.V. Pynyaev, Vestnik PAGS, . - 182 (2010)

8. D.V. Sevastyanov, Fundamentals of country studies and international tourism: manual for universities (2008)

9. Rural tourism: save the ordinary farmer, www. agritourism. ru/

10. I.V. Smirnova, Bulletin of the Mari state University, 1(13) (2014)

11. Current state of agritourism in the regions of the Russian Federation: passwords and turnouts, http://www.agroxxi.ru/

12. V. Tkachuk, Agrarian economy, 1-2, 83 (2012) 
13. A.I. Tarasenok, Journal of the Institute of entrepreneurial activity, 1 (18), 80 (2018)

14. M. Schneider, L. Przezburska, Economic and social problems of agribusiness development at the turn of the 21st century, 2, 110 (2000)

15. G.V. Cherevko, G.I. Shimechko, The economic caapc, 5, 132(2011)

16. S.E. Terentyev, O.V. Lazko, A.B. Belokopytov, Proceedings of the 1st international scientific conference modern management trends and the digital economy: from regional development to global economic growth (MTDE 2019),46(2019)

17. J. Sikora Agritourism: entrepreneurship in rural areas (2012)

18. J. Zawadka, Ekonomiczno-spoleczna determinacja rozvoj agroturystyczna w Lublinsky regionie (na przykladach wybranych gmin) (2000)

19. I M. Wozniak, S. Dziedzic, Innovation in tourism (2017) 